\title{
An overview of the taxation of residential property: is it a good idea?
}

\author{
MARTA RODRIGUEZ-VIVES, Ph.D.* \\ MIGUEL ANGEL GAVILAN-RUBIO, Ph.D."
}

Preliminary communication ${ }^{* *}$

JEL: H21, H24, H71, R31, R38

https://doi.org/10.3326/pse.45.2.5

\footnotetext{
* The opinions expressed herein are those of the authors and do not necessarily reflect the views of the ECB, Bank of Slovenia or the Eurosystem. We want to thank three anonymous referees for their suggestions for improving this work. Likewise, the authors want to express their gratitude to the participants and the discussants of the $4^{\text {th }}$ Public Sector Economics Conference (Zagreb, 24 October 2019) where a preliminary version of this article was discussed. Any errors are the sole responsibility of the authors.

${ }^{* *}$ Received: May 29, 2020

Accepted: February 8, 2021
}

Marta RODRIGUEZ-VIVES

Principal Economist at Fiscal Policies Division, European Central Bank, Sonnemannstrasse 20,

60314 Frankfurt am Main, Germany

e-mail: marta.rodriguez@ecb.europa.eu

ORCiD: 0000-0003-1190-6599

Miguel Angel GAVILAN-RUBIO

Researcher at Analysis and Research Division, Bank of Slovenia, Slovenska 35, 1505 Ljubljana, Slovenia e-mail: Miguel-Angel.Gavilan-Rubio@bsi.si

ORCiD: 0000-0002-0001-9663 


\section{Abstract}

This article examines the taxation of property in the residential market as a potential revenue-raising tool in public finance. Economists generally consider taxing property to be less distortionary than taxing other tax bases. It ranks well in terms of trade-offs across long-term growth and inequality considerations. Although countries have different societal preferences, recourse to property taxation is not generally widespread. Using panel data methods and stochastic frontier analysis, we provide evidence that government revenue from property taxation is relatively inelastic to house price and quantity developments, and that countries with a higher implicit tax rate tend to be more efficient at collecting the revenue. Despite the increase of prices since 2014, low revenues can be the result of low effective tax rates and outdated house valuation systems.

Keywords: property tax, households, housing policies, housing prices, wealth inequality

\section{INTRODUCTION}

Developments in housing markets impact economic growth, wealth inequality (affecting household investment decisions and indebtedness) and financial stability (a house can be a collateral asset for banking lenders).

The government sector plays a relevant role in the dynamics of real estate markets. First, governments pursue housing policy objectives aimed at the provision of adequate and affordable housing. ${ }^{1}$ There are several tools at the disposal of governments, such as taxation, social housing and regulations. Fiscal policies can also impact household indebtedness through the tax incentives it creates for holding property or contracting mortgages. In particular, several countries provide tax reliefs (either deductions or tax credits, which are typically capped) for mortgage principal repayments and/or for interest payments.

Second, property taxation is also a valuable tool used by governments to generate income, which is the focus of this article. It is not straightforward to find the best combination of revenue raising fiscal instruments to finance public spending in a budget (Rodríguez-Vives, 2019). Taxes are generally not desirable as they distort markets, but property taxation is seen as a potential revenue-raising tool in a relatively growth- and equity-friendly manner. This particularly holds true in a case in which there is a need for consolidation in order to keep public finances sustainable. Property taxation appears to be relatively growth-friendly as it mainly taxes immovable bases. ${ }^{2}$ Property taxes also have special features compared to others, such as their visibility and relatively inelasticity (i.e. recurrent property taxes).

\footnotetext{
${ }^{1}$ For more details, OECD (2019a) and its "Public policies towards affordable housing" section.

${ }^{2}$ See Acosta-Ormaechea and Yoo (2012). According to Roeger and Veld (2010), property taxes are considered the most growth-friendly type of tax. The authors set a model with a tax on housing property, in which increments in this tax negatively affect housing investment. However, it does not directly distort the provision of the inputs to production and household consumption decisions. Moreover, by making investments in productive capital relatively more attractive than investment in housing, it leads to a higher stock of productive capital and more production.
} 
Moreover, property taxation is currently attracting more attention from policymakers as its yields are still relatively low compared to the taxation of other goods. For instance, Norregaard (2013) concludes that taxing immovable property has a potential for revenue growth of around $2 \%$ of GDP in developed countries. Country recommendations by international institutions (e.g., the European Commission, OECD) generally include shifting taxes from (lower wage) labour to taxes less detrimental for long-term growth, such as property taxes (ECB, 2017). Hence, increasing the recourse to property taxation could provide a potential source for government revenue by broadening tax bases, tax rates and/or abolishing tax exemptions. However, a greater recourse to housing taxation may have some undesirable outcomes as well, such as dampening housing investment cycles (Cavalleri, Cournède and Ziemann, 2019).

This article approaches the policy question of taxing property from different angles. ${ }^{3}$ Section 2 discusses the advantages and disadvantages of taxing property. Section 3 presents some stylized facts on property tax revenues across developed countries. Section 4 proposes an econometric model analysing the revenue potential of taxing property. Section 5 outlines a set of conclusions.

\section{TAXING PROPERTY}

In the OECD taxonomy, property taxes are divided into two broad groups: recurrent taxes and other taxes (non-recurrent property taxes). Recurrent taxes on the property are typically paid annually, at sub-national level and linked to some measure of the value of the property. However, other taxes, such as taxes on financial and capital transactions, are paid when the ownership of the property changes hands. Table A1 in the appendix shows the different taxes applicable in the life cycle of the housing market and the economic rationale behind them. Section 3 shows substantial heterogeneity on how countries levy recurrent and other property taxes. ${ }^{4}$

Following the economic rationale, property taxation ranks high in terms of growth and equity effects in relation to other fiscal instruments. In particular, other property taxes are one of the best possible choices if there are needs for consolidation, after subsidies and pensions, according to the generic hierarchy of consolidation instruments (OECD, 2013a; Cournède, Goujard and Pina, 2013). Recurrent property taxes rank in the middle of tax instruments, after income taxation and environmental taxes. Arnold (2008) finds that recurrent property taxes appear to be the most growth-friendly, followed by consumption and personal income taxes. Corporate income taxes appear to have the most negative effect on GDP per capita. Grdinić et al. (2017) find in a panel of 20 countries that personal income taxes have the highest negative impact on economic growth, while property taxes

\footnotetext{
${ }^{3}$ Although taxing property refers to both residential and commercial property, this article focuses on residential property and the household sector.

${ }^{4}$ The taxpayers can be households, individuals, or corporations. Also, the property can either refer to residential or commercial real estate. Although a more granular assessment is warranted, this is outside the scope of this paper. Instead, we refer to taxing property in a generic way, focusing on the household sector and residential real estate by default.
} 
showed the least negative impact. The authors find that a revenue-neutral growthoriented tax reform would shift part of the revenue base from income taxes (especially corporate taxes) to recurrent taxes. In terms of equity friendliness, rises in other taxes, such as on net wealth or inheritances and gifts, are typically seen as improving the progressivity and fairness of the tax system (IMF, 2018; Bahl and Martínez-Vasquez, 2008).

From the lifecycle of a property, there are different taxing options depending on the economic transaction involved: buying, holding, renting, selling or bequeathing (table A1 in the appendix).

Taxing property also raises complex distributional questions. On the one hand, analysing the income inequality levels in the society (e.g. Gini coefficient) is an important indicator of the effectiveness of the government action in the economy. More progressive tax systems make the post-tax income distribution more equal (e.g. Förster, Llena-Nozal and Nafilyan, 2014). On the other hand, household (net) wealth, which is composed of real and financial assets, is also a crucial topic. In the euro area, around $65 \%$ of households have accumulated real estate wealth. ${ }^{5}$ Household main residence (HMR) is the most significant component of real assets in the euro area (60.3\% in 2017), followed by other estate real assets (24.1\% in 2017). The conditional median for HMR rose by $2.7 \%$ to $€ 165,700$ in 2017 from 2014, albeit there was strong heterogeneity across countries and income distributions. A significant influence on real estate wealth accumulation is related to the changes in the value of the underlying asset (e.g. capital gains on real estate holdings). Moreover, housing is considered one of the key dimensions for measuring well-being (OECD, 2013b).

An alternative way for policymakers to look at whether real estate is undertaxed is to compare how property is taxed relative to other investment or consumption goods. This fact makes the taxation of owner-occupied properties a concept that is relative to other assets. Figure 1 illustrates the dichotomy of a dwelling purchase. Housing is more than an investment good as it provides a habitat to households, so owner-occupied or holiday homes can also be seen as a (durable) consumption good. Hence, several policy objectives that may justify housing being undertaxed, such as addressing market failures in low homeownership ratios and increasing social cohesion. However, second homes providing rental income can, on the other hand, be seen as only investment goods. In national accounts, household purchases of dwellings are accounted for as investment (gross fixed capital formation) and not as consumption expenditure. Moreover, the owners of dwellings are regarded as producing housing services either for themselves or for tenants. ${ }^{6}$

\footnotetext{
${ }^{5}$ According to the third wave of the ECB's Household Finance and Consumption Survey (HFCS), which refers to 2017 data - for more details see Household Finance and Consumption Network (2020).

${ }^{6}$ Housing services provided by homeowner-occupiers are imputed as being equal to the rents they would have paid for comparable housing. It implies that the production of services (rental or imputed) from owner-occupied (imputed) and tenant-occupied dwellings (rental) are part of GDP. The arbitrariness lies in the imputation method. According to Lequiller and Blades (2014), a long-term upward trend in homeownership would automatically produce a downward trend in the total value of actual rents (and thus in GDP, all things being equal) and make it difficult to compare the output of different countries because homeownership rates vary across countries.
} 


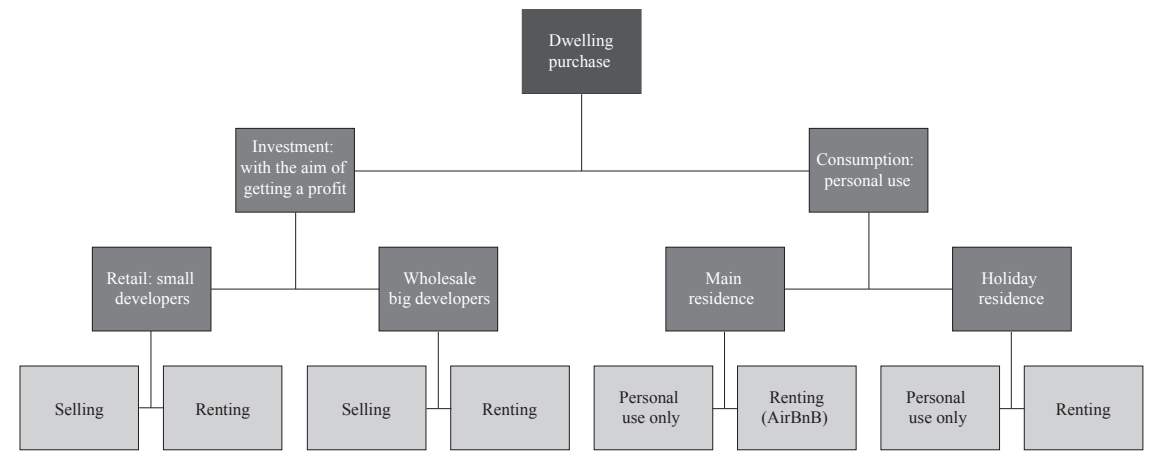

Source: Own representation.

As an investment, real estate competes with alternative investments in terms of returns, i.e. pension funds, financial assets, or opening a business. In theory, tax systems should provide a level playing field for asset portfolio choices, tax neutrality, as it is called, to foster the efficiency and fairness of the system. However, the OECD (2018) remarks on the lack of neutrality in the 40 countries where the marginal effective tax rates (METRs) on different assets were calculated. Their results show that the most tax-favoured assets are pension funds, owner-occupied residential property, and savings accounts. However, rental property is often subject to relatively high METRs due to the application of progressive marginal personal income tax (PIT) rates, capital gains taxes and significant property taxes.

\section{PROPERTY TAXATION: STYLIZED FACTS IN ADVANCED COUNTRIES}

This section presents the recent stylized facts regarding property taxation. There are several peer comparisons of property tax revenues (e.g. IMF, OECD, European Commission/Eurostat, international consulting and tax companies). Overall, few countries have significantly increased property tax collection in the last decade, although many developed countries have improved their structure or yields in their reform efforts to increase their revenues (e.g. Greece).

Revenue from taxing property amounts to almost $2 \%$ of GDP on average, which represents a small contribution to total revenue, of almost $6 \%$. Figure 2 shows that the contribution of property taxation to total revenues is generally more substantial in countries with higher property tax rates (e.g. the UK, the US, Canada, Greece, France). At the other extreme, there are countries where the contribution of property tax to total government revenue is proportionally and significantly lower than that of their peers (e.g. Croatia, Austria, Estonia, Slovenia).

Albeit there is country heterogeneity in the composition of property taxation, recurrent taxes are far the most extensively used category of property taxation across countries. Capital taxes related to the possession and transfer of immovable 
property are also relevant. Although a majority of countries apply inheritance and gift taxes, the amount collected is minimal (below $0.5 \%$ of GDP) with some exceptions (e.g. France, Belgium, Japan and the UK). Only a minority of countries tax net wealth or the possession of specific assets.

\section{Figure 2}

Components of property tax, percentage of GDP (2018, in \%)

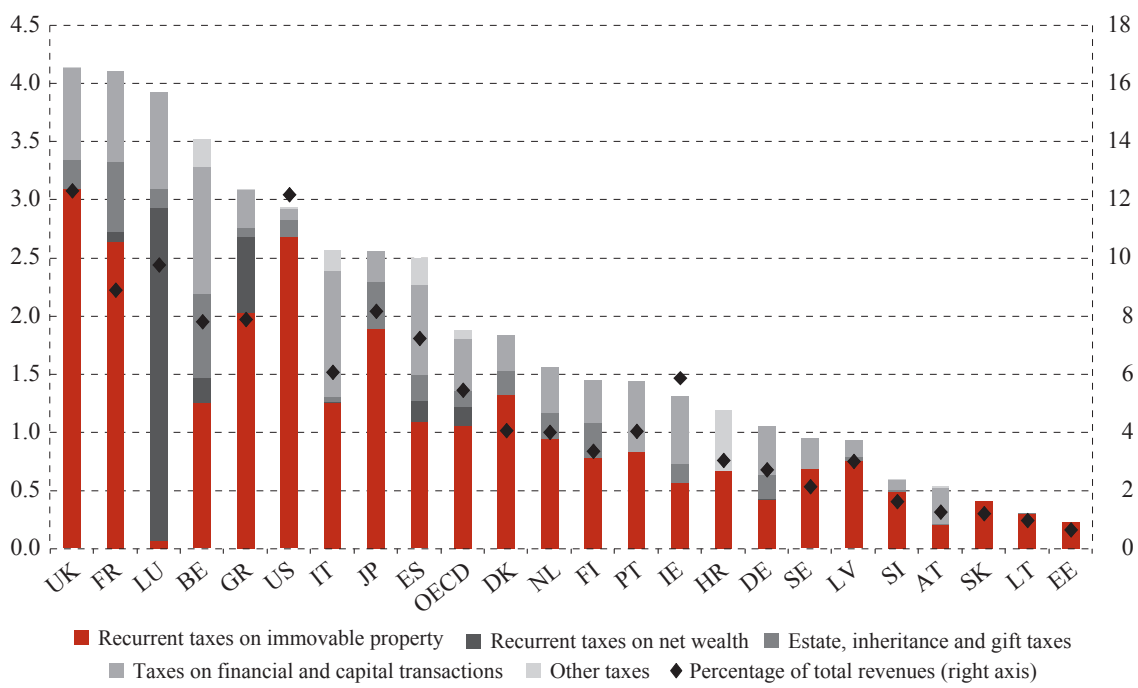

Note: For Greece, Japan and the OECD average the data refer to 2017. Recurrent taxes on net wealth include current taxes on capital; capital transactions include taxes on stamp duties; and "other taxes" include other non-recurrent taxes on property (capital levies) and other recurrent taxes on property (current taxes on capital). Own representation.

Source: Authors based on OECD Revenue Statistics database and Eurostat.

Figure 3 illustrates that recurrent taxes have substantially increased compared to the pre-crisis levels, with a few notable exceptions (e.g. Croatia, Austria, Estonia, Germany, Luxembourg, Lithuania, Slovakia, Sweden and Japan). By contrast, other taxes remain at a level similar to that of before the crisis for most countries. Several countries have experienced an increase in the percentage of other property taxation, which is particularly substantial and recent in the case of the US. This category is becoming, however, less relevant for a group of countries with a high share of homeownership (e.g. Ireland, the Netherlands, Portugal, Spain and the UK).

Looking ahead, taxing residential property still seems to be a particularly dynamic source for growth for public revenue collection. Real housing prices have increased in the majority of advanced countries as have the purchases made by households in recent years. Household investment rate in the OECD averaged $6.6 \%$ of the gross disposable income of households in 2018 (only 2.2 percentage points below its peak value in 2007). According to figure $4 \mathrm{a}$, we can observe that in some countries, such as in Spain and Greece, the investment rate has not reached 2007 levels yet. Regarding the evolution of house prices, the latest release of 
Eurostat (April 2020) ${ }^{7}$ points to a continuation of the upward trend initiated in 2014. Moreover, several OECD countries have experienced reductions in house prices with respect to their incomes since 2007, such as in the Baltics, which could be an indication of improved affordability (figure $4 \mathrm{~b}){ }^{8}$

\section{Figure 3}

Property tax revenue, as percentage of total government revenue (2018 vs. 2007, in \%)

(a) Recurrent taxes on property

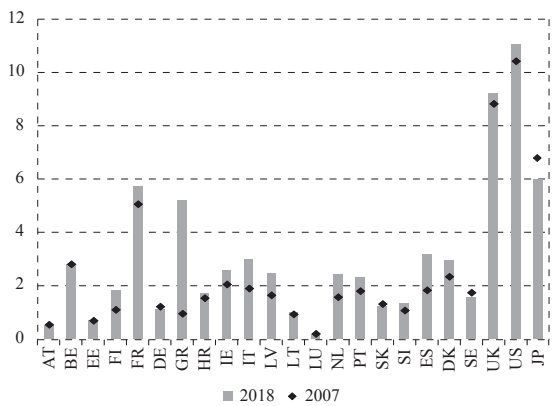

(b) Other taxes on property

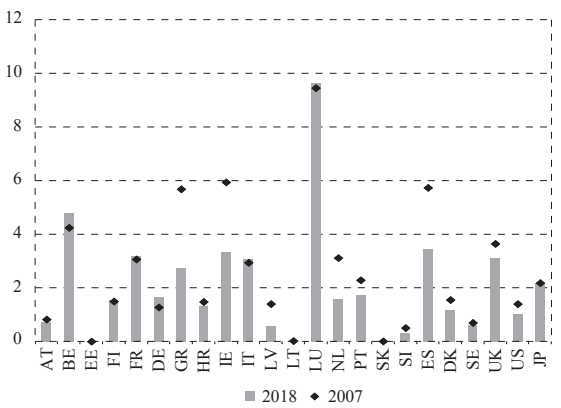

Note: For Greece, Japan and OECD average the data refer to 2017. "Other taxes on property" includes taxes on net wealth, heritage and gift taxes, taxes on financial and capital transactions, other non-recurrent taxes on property and other recurrent taxes on property.

Source: Authors based on OECD Revenue Statistics database and Eurostat.

\section{Figure 4}

Residential property developments (in \%)

(a) Gross household investment rate (GFCF-to-GDI ratio)

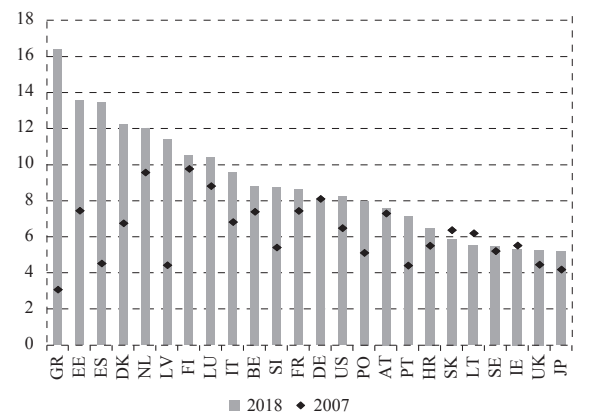

(b) Price-to-income ratio

(\% change 2007-2018)

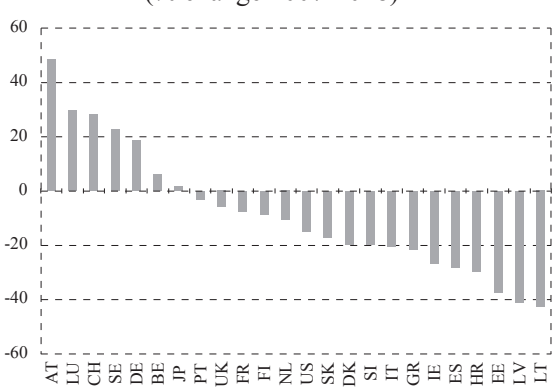

Source: Eurostat, IMF database (IMF.org/housing).

\footnotetext{
${ }^{7}$ With an average increase of 4.2\% in 2019Q4 in comparison to 2018Q4 - according to Eurostat's house price data.

${ }^{8}$ There are some patterns observed when considering the investment rate and prices together. We can observe some countries such as Spain and Greece, where both investment rate and price-to-income ratio have fallen, indicating a lack of demand in the market. By contrast, Germany, Japan and Austria have reached investment rates similar to pre-crisis levels and increases in prices with respect to their disposable incomes.
} 
(a) Implicit tax rate on immovable property (revenue-to-base value ratio)

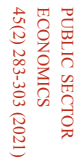

(b) Growth rate dwelling stock (\% change $2007-2017 *$ )

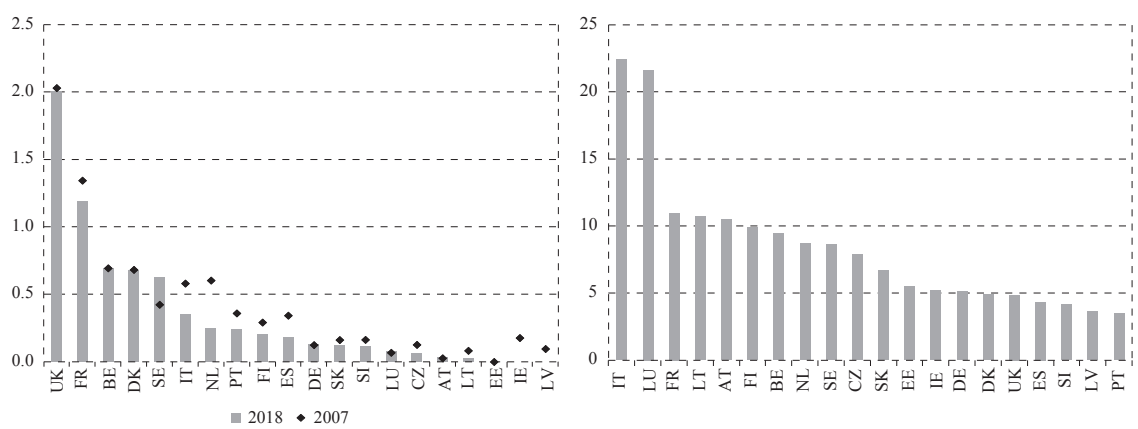

* The last available years for Austria, Italy and Luxemburg are 2016, 2015 and 2013 respectively. Source: Barrios et al. (2019), Eurostat and ECB database.

In practice, increasing the recourse to property taxation also faces many political economy obstacles. This tax is particularly unpopular and difficult to implement. The property tax reforms introduced in 2019 were limited in number and scope. The focus has been on increasing taxes on high-value immovable property (OECD, 2019b). Figure 5 illustrates this fact. Comparing the implicit tax rate on immovable property in 2017 with pre-crisis rates, we find that there has been an effort to increase the recurrent revenues from residential properties in the Netherlands, Spain, Portugal, Ireland and Italy. However, the increment in government revenue is not proportional to the increment in the tax base, as we can observe in the growth of dwelling stock in those countries over the same period.

Going forward, the planning of timing, scope and sequencing is essential for reforming property taxation (European Commission, 2012). However, this also requires excellent coordination of the institutional framework in place dealing with the national housing policy (e.g. the ministry of finance/tax department, the financial supervision authority, the national central bank) and the sub-national/ local authorities.

\section{AN EMPIRICAL ANALYSIS IN ADVANCED COUNTRIES}

In this section, we explore to what extent country differences in implicit tax rates on immovable property between 1995 and 2017 are attributable to fluctuations in the base, via quantity and prices, and some other macroeconomic variables. This exercise also includes the sharp drop in house prices experienced by several countries during 2008-2009 and the more recent recovery in 2014.

\subsection{METHODOLOGY}

We implement two basic empirical models to look at the relationship between the implicit property tax rate and potential macroeconomic variables. Although the 
complexity of the housing market dynamics is not fully captured by the model, the aim of this paper is to focus on the revenue-raising capacity of property taxation from a public finance perspective. We estimate different combinations in two different frameworks: panel data analysis and stochastic frontier analysis. The reduced panel model is given by:

$$
\log (\operatorname{IRTRI})_{i, t}=\beta_{0}+\beta_{1} g_{i, t}^{S D}+\beta_{2} g_{i, t}^{\overline{P M 2}}+\beta_{3} X_{i, t}+\varepsilon_{i, t}
$$

where $\log (I R T R I)$ denotes the implicit recurrent tax rate on immovable property, $g_{i, t}^{S D}$ the growth rate of the stock of dwellings, $g_{i, t}^{\overline{P M 2}}$ the growth rate of the average price per square meter, and $X_{i, t}$ a set of macroeconomic variables with potential impact in the explanatory variable; and $\varepsilon_{i, t}$ is an error term with the usual assumptions.

Regarding stochastic frontier analysis, and following Fenochietto and Pessino (2013), we can understand the implicit recurrent tax rate as the output of a production function, which is produced by different inputs. One of the advantages of this methodology is that it assumes that there are inefficiencies. In our case, these inefficiencies would represent the inability of governments to collect the taxes. The frontier model is based on Kumbhakar and Lovell (2000), and is given by:

$$
\log (\operatorname{IRTRI})_{i, t}=\beta_{0}+\beta_{1} g_{i, t}^{S D}+\beta_{2} g_{i, t}^{\overline{P M 2}}+\beta_{3} X_{i, t}+\varepsilon_{i, t}+v_{i}-u_{i}
$$

where the idiosyncratic component, $v_{i}$, is assumed to be independently $N\left(0, \sigma_{v}\right)$ distributed over the observations, and the inefficiency term, $u_{i}$, is strictly positive and assumed to be independently half normal, $|N(0, \sigma)|$, and using the $\sigma$ parametrization of the normal distribution. The expectation is then given by $\mathrm{E}(u)=\sigma \sqrt{2 / \pi}$ and variance $\operatorname{var}(u)=\sigma^{2}\left(1-\frac{2}{\pi}\right)$.

\subsection{THE DATA}

We use a compacted version of the data presented in previous sections. The dataset is an unbalanced panel and comprehends 20 EU countries over 23 periods, from 1995 to $2017 .{ }^{9}$ The dataset is composed of eight variables: the logarithm of the implicit recurrent tax rate on immovable property, the growth rate of the stock of dwellings, the growth rate of the average price per square meter, the logarithm of the household debt-to-GDP ratio, the logarithm of the GINI index, transfer tax rates, interest tax rates, and the long-term interest rates (LTIR). ${ }^{10}$ The implicit recurrent tax rate on immovable property is defined as the ratio of revenue from recurrent taxes on immovable property collected from households to the net stock of dwellings in the household sector.

\footnotetext{
${ }^{9}$ The 20 selected countries are Austria, Belgium, Czech Republic, Denmark, Finland, France, Germany, Ireland, Italy, Latvia, Lithuania, Luxembourg, Netherlands, Portugal, Slovakia, Slovenia, Spain, Sweden and the United Kingdom.

${ }^{10}$ We initially considered other variables, such as GDP per head (constant PPS) and inflation. These two variables never were significant. However, they did cause high group heterogeneity, serial correlation and collinearity, affecting the overall estimation and performance of the models. We finally decided not to include them in the models.
} 
The variables have been transformed using growth rates and logarithms. These two transformations have the advantages of setting the explanatory variables in the same metric, and of mitigating potential problems with heteroskedasticity and serial correlation, as some variables were non-stationary processes. Table A2 (in the appendix) summarises the main descriptive statistics of each variable used in the regressions, showing the standard deviations in the overall dataset, within and between groups.

\subsection{RESULTS}

\subsubsection{PANEL DATA ANALYSIS}

Table 1 shows the results of regressing different combinations of variables on the implicit tax rate using panel data analysis based on equation (1). ${ }^{11}$ Given the metric of the variables, the fitted values might not have a straightforward interpretation. However, we find that the sign of these values is consistent.

Both growth rate of the stock of dwellings and growth rate of the average price per square meter negatively affect the implicit property tax rate. While these results seem to be counterintuitive, this is the result of the implicit property tax rate construction. Both variables affect the tax base, i.e., determining the total value of the net stock of dwellings, and this is the denominator of the implicit property tax rate. Presumably, we can assume that both variables also affect the total revenues (the numerator of the implicit property tax rate). However, the negative sign in the regressions suggests that price and quantity elasticities of the revenues are inelastic. This finding implies that the revenue from recurrent taxes on immovable properties increases proportionally less than the value of the tax base. Also, and according to the estimations, the effect via quantities is more significant than the effect via prices, suggesting that a generalised problem in a Europe with a restrictive housing supply is also making governments lose potential revenues. However, these two variables turn to be less significant when we introduce other explanatory variables.

Regarding the effects of the household debt-to-GDP ratio, the results suggest that it has a positive effect on the implicit property tax rate. This result is contrary to the findings from some authors, ${ }^{12}$ as it is argued that tax relief on mortgage interest payments results in revenue being lost and constitutes housing tax expenditure, which would imply a negative coefficient in the estimations. However, the intuition behind these results is as follows. The main driver of the average household debt are mortgages, and we could expect two non-exclusive effects to explain the reason for some countries having households that are more in debt.

\footnotetext{
${ }^{11}$ We performed the Hausman Test for each specification, resulting in Random Effects models in all of them. See the P-values of the Hausman Test at the bottom of the table.

${ }^{12}$ For example, see Fatica and Prammer (2018) and European Commission (2015) for more details.
} 


\section{TABLE 1}

Estimation of implicit recurrent tax rate functions using panel data analysis random effects (selected EU countries, 1995-2017)

Log implicit recurrent tax rate on immovable property

\begin{tabular}{|c|c|c|c|c|c|c|}
\hline & $\begin{array}{c}\text { Model } 1 \\
\text { (RE) }\end{array}$ & $\begin{array}{c}\text { Model } 2 \\
\text { (RE) }\end{array}$ & $\begin{array}{l}\text { Model } 3 \\
\text { (RE) }\end{array}$ & $\begin{array}{c}\text { Model } 4 \\
\text { (RE) }\end{array}$ & $\begin{array}{c}\text { Model } 5 \\
\text { (RE) } \\
\end{array}$ & $\begin{array}{c}\text { Model } 6 \\
\text { (RE) }\end{array}$ \\
\hline \multirow{2}{*}{ Constant } & $-1.478^{* * *}$ & $-4.043 * * *$ & 5.356 & 1.078 & 0.0953 & 2.145 \\
\hline & $(0.28)$ & $(0.58)$ & $(3.51)$ & $(3.23)$ & $(3.04)$ & $(3.14)$ \\
\hline \multirow{2}{*}{$\begin{array}{l}\text { Growth } \\
\text { of stock } \\
\text { dwellings }\end{array}$} & $-0.1250 * * *$ & $-0.0959 * * *$ & $-0.1310 * * *$ & $-0.1200 * * *$ & $-0.1320 * * *$ & $-0.0869 * *$ \\
\hline & $(0.04)$ & $(0.03)$ & $(0.05)$ & $(0.04)$ & $(0.04)$ & $(0.04)$ \\
\hline \multirow{2}{*}{$\begin{array}{l}\text { Growth of } \\
\text { price of } \mathrm{m}^{2}\end{array}$} & $-0.0076 * * *$ & -0.0011 & $-0.0081 * * *$ & -0.0013 & -0.0017 & -0.0048 \\
\hline & $(0.00)$ & $(0.00)$ & $(0.00)$ & $(0.00)$ & $(0.00)$ & $(0.00)$ \\
\hline \multirow{2}{*}{$\begin{array}{l}\text { Log HH } \\
\text { debt ratio }\end{array}$} & & $0.5590^{* * *}$ & & $0.7150^{* * *}$ & $0.7480^{* * *}$ & $0.5560^{* * *}$ \\
\hline & & $(0.11)$ & & $(0.18)$ & $(0.18)$ & $(0.17)$ \\
\hline \multirow{2}{*}{ Log Gini index } & & & $-1.9890^{*}$ & $-1.7090^{*}$ & $-1.4280^{*}$ & $-1.7260 * *$ \\
\hline & & & $(1.04)$ & $\begin{array}{l}(0.96) \\
\end{array}$ & $(0.86)$ & $(0.87)$ \\
\hline \multirow{2}{*}{$\begin{array}{l}\text { Transfer } \\
\text { tax rate }\end{array}$} & & & & & $-0.0886^{*}$ & $-0.0893^{*}$ \\
\hline & & & & & $(0.05)$ & $(0.05)$ \\
\hline \multirow{2}{*}{$\begin{array}{l}\text { Interests } \\
\text { income tax rate }\end{array}$} & & & & & $0.0077 * * *$ & $0.0077 * * *$ \\
\hline & & & & & $(0.00)$ & $(0.00)$ \\
\hline \multirow{2}{*}{$\begin{array}{l}\text { Long term } \\
\text { interest rate }\end{array}$} & & & & & & $-0.0471 * * *$ \\
\hline & & & & & & $(0.01)$ \\
\hline $\begin{array}{l}\text { No of } \\
\text { observations }\end{array}$ & 338 & 337 & 256 & 255 & 255 & 255 \\
\hline No of countries & 19 & 19 & 19 & 19 & 19 & 19 \\
\hline R2 overall & 0.0258 & 0.2610 & 0.0168 & 0.2190 & 0.2140 & 0.1780 \\
\hline R2 within & 0.0332 & 0.0795 & 0.0736 & 0.1200 & 0.1720 & 0.2040 \\
\hline R2 between & 0.0367 & 0.2960 & 0.0277 & 0.2370 & 0.2130 & 0.1770 \\
\hline Hausman test ${ }^{a}$ & 0.8142 & 0.1058 & 0.8204 & 0.5624 & 0.2053 & 0.2578 \\
\hline
\end{tabular}

Note: Standard errors in parentheses. Standard errors are obtained using robust estimations. $* p<0.10, * * p<0.05$, and $* * * p<0.01$.

${ }^{a} p$-values reported.

On the one hand, housing prices can be proportionally more extensive than in other countries, which would result in larger mortgages and higher bases. Because most of the recurrent property taxes are defined as rates, this would increase the revenues. On the other hand, it can also be a consequence of a larger fraction of the population having mortgages, which results in a larger fraction of owner-occupied dwellings, facilitating identification of the taxpayer, and making it easier to increase revenues. ${ }^{13}$ Along these lines, we should also consider the effect of the Gini index, which is harmful in all the specifications. This result means that countries with a low Gini index have a larger implicit property tax rate. Intuition here is in line with the idea of identifying taxpayers. A more homogeneous society should be related to a larger fraction of owner-occupied dwellings, which makes identification of the taxpayer and increasing revenues easier.

\footnotetext{
${ }^{13}$ There is currently an excellent tax offshoring debate in the UK, as unknown ownership has severe consequences in the collection of Council Taxes, which could lead to potential revenue losses.
} 
Thus, the empirical evidence suggests that the effects of a larger base and, more significantly, the easier identification of the taxpayer overweight the loss from tax relief on mortgages.

Models 5 and 6 include alternative tax rates. While the effect of the transfer tax rate is negative, which implies that there is a shift from the recurrent tax to the transfer tax, the effect of the interest income tax rate is positive. In the case of the transfer tax, it could be argued that an increment in the property tax rate could lead to a delay in the dynamics of the housing market. Therefore, one could expect a reduction in the implicit recurrent tax rate. However, the result for the interest income tax rate is more interesting. Rises in the interest income tax rate increase the implicit recurrent tax rate because the returns from immovable property are included - the numerator of the implicit recurrent tax rate. Thus, increments in the rate increase revenues.

The last considered variable is long-term interest rates. Its sign is negative, which is the result of its effect on mortgages. Increments in the long-term interest rates make mortgages more expensive, which slows down the market and constrains the collection of revenues. Also, an increment in interest rates might increase the number of applications for tax reliefs (as a consequence of the higher interest payments).

\subsubsection{STOCHASTIC FRONTIER ANALYSIS}

Table 2 shows the results of regressing the same combinations of variables on the implicit tax rate but using stochastic frontier analysis based on equation (2). ${ }^{14}$ This alternative approach has a twofold use. On the one hand, it acts as a robustness check for the panel data analysis. On the other hand, it allows us to analyse the efficiency of the different tax systems (conditional on the selected explanatory variables) by estimating the efficiency scores.

Regarding the first proposition, we find that the signs and the coefficients are very alike in the two methodologies, suggesting that the results are robust to the estimation method. Also, when the values of the coefficients from one specification to the others are compared, there is no significant change. In the case of the growth rate of the stock of dwellings and the growth rate of the average price per square meter, the introduction of a new explanatory variable makes the coefficients smaller, reducing their impact on the explained variable. For these reasons, the interpretation of the results is the same in both cases.

\footnotetext{
${ }^{14}$ We estimated Time-invariant (TI) and Time-varying decay (TVD) frontiers and, in all feasible cases (some models did not converge when TVD specifications were used), the coefficient related to the Time-varying decay was insignificant, suggesting the use of Time-invariant models.
} 
TABLE 2

Estimation of implicit recurrent tax rate functions using stochastic frontier analysis (selected EU countries, 1995-2017)

Log implicit recurrent tax rate on immovable property

\begin{tabular}{|c|c|c|c|c|c|c|}
\hline & $\begin{array}{l}\text { Model } 7 \\
\text { (TI) }\end{array}$ & $\begin{array}{l}\text { Model } 8 \\
\text { (TI) }\end{array}$ & $\begin{array}{l}\text { Model } 9 \\
\text { (TI) }\end{array}$ & $\begin{array}{l}\text { Model } 10 \\
\text { (TI) }\end{array}$ & $\begin{array}{l}\text { Model } 11 \\
\text { (TI) }\end{array}$ & $\begin{array}{l}\text { Model } 12 \\
\text { (TI) }\end{array}$ \\
\hline \multirow{2}{*}{ Constant } & $1.047^{* * *}$ & $-1.737 * * *$ & $7.9910 * * *$ & 3.330 & 2.427 & $4.475^{*}$ \\
\hline & $(0.31)$ & $(0.65)$ & $(2.41)$ & $(2.43)$ & $(2.34)$ & $(2.41)$ \\
\hline \multirow{2}{*}{$\begin{array}{l}\text { Growth } \\
\text { of stock } \\
\text { dwellings }\end{array}$} & $-0.1250^{* *}$ & $-0.0955^{* *}$ & $-0.1310 * *$ & $-0.1200 * *$ & $-0.1310^{* * *}$ & $-0.0854 *$ \\
\hline & $(0.05)$ & $(0.05)$ & $(0.05)$ & $(0.05)$ & $(0.05)$ & $(0.05)$ \\
\hline \multirow{2}{*}{$\begin{array}{l}\text { Growth of } \\
\text { price of } \mathrm{m}^{2}\end{array}$} & $-0.0076 * *$ & -0.0012 & $-0.0080 * *$ & -0.0012 & -0.0017 & -0.0049 \\
\hline & $(0.00)$ & $\begin{array}{l}(0.00) \\
\end{array}$ & $(0.00)$ & $(0.00)$ & $(0.00)$ & $(0.00)$ \\
\hline \multirow{2}{*}{$\begin{array}{l}\text { Log } \mathrm{HH} \\
\text { debt ratio }\end{array}$} & & $0.5530^{* * *}$ & & $0.7200 * * *$ & $0.7410 * * *$ & $0.5450 * * *$ \\
\hline & & $(0.11)$ & & $(0.15)$ & $(0.15)$ & $(0.17)$ \\
\hline \multirow{2}{*}{ Log Gini index } & & & $-1.9590 * * *$ & $-1.6790 * * *$ & $-1.4390 * *$ & $-1.7390 * * *$ \\
\hline & & & $\begin{array}{l}(0.67) \\
\end{array}$ & $(0.63)$ & $(0.62)$ & $(0.62)$ \\
\hline \multirow{2}{*}{$\begin{array}{l}\text { Transfer } \\
\text { tax rate }\end{array}$} & & & & & $-0.0904 * * *$ & $-0.0904 * * *$ \\
\hline & & & & & $(0.03)$ & $(0.03)$ \\
\hline \multirow{2}{*}{$\begin{array}{l}\text { Interests } \\
\text { income tax rate }\end{array}$} & & & & & $0.0076^{* *}$ & $0.0076^{* *}$ \\
\hline & & & & & $(0.00)$ & $(0.00)$ \\
\hline \multirow{2}{*}{$\begin{array}{l}\text { Long term } \\
\text { interest rate }\end{array}$} & & & & & & $-0.0476 * * *$ \\
\hline & & & & & & $(0.02)$ \\
\hline \multicolumn{7}{|l|}{ Log sigma2 } \\
\hline \multirow{2}{*}{ Constant } & 0.4420 & 0.1680 & 0.3760 & 0.0957 & 0.1400 & 0.1950 \\
\hline & $(0.34)$ & $(0.32)$ & $(0.33)$ & $(0.32)$ & $(0.35)$ & $(0.36)$ \\
\hline \multicolumn{7}{|l|}{ Log t gamma } \\
\hline \multirow{2}{*}{ Constant } & $1.8300 * * *$ & $1.6020 * * *$ & $2.0310 * * *$ & $1.8320 * * *$ & $1.9530 * * *$ & $2.0610 * * *$ \\
\hline & $(0.40)$ & $(0.39)$ & $(0.38)$ & $(0.38)$ & $(0.41)$ & $(0.42)$ \\
\hline \multicolumn{7}{|l|}{$\mathrm{mu}$} \\
\hline \multirow{2}{*}{ Constant } & $2.4760^{* * *}$ & $2.2510 * * *$ & $2.7080 * * *$ & $2.3600 * * *$ & $2.2210 * * *$ & $2.1780 * * *$ \\
\hline & $(0.44)$ & $(0.42)$ & $(0.52)$ & $(0.48)$ & $(0.41)$ & $(0.40)$ \\
\hline $\begin{array}{l}\text { No of } \\
\text { observations }\end{array}$ & 338 & 337 & 256 & 255 & 255 & 255 \\
\hline No of countries & 19 & 19 & 19 & 19 & 19 & 19 \\
\hline AIC & 537.7 & 506.6 & 369.4 & 339 & 328.8 & 322.4 \\
\hline $\mathrm{BIC}$ & 560.6 & 533.3 & 394.2 & 367.3 & 364.2 & 361.3 \\
\hline Log likelihood & -262.8 & -246.3 & -177.7 & -161.5 & -154.4 & -150.2 \\
\hline
\end{tabular}

Note: Standard errors in parentheses. Standard errors are obtained using robust observed information matrix. $* p<0.10, * * p<0.05$, and $* * * p<0.01$.

However, and regarding the efficiency analysis according to table 2, the empirical evidence suggests that the higher the implicit property tax rate, the more efficient the tax system is - or the other way around, as we cannot establish a causal relationship between the two variables. This relationship is apparent when we plot efficiency versus the average implicit property tax rate. 
(a) Ranking estimated efficiency

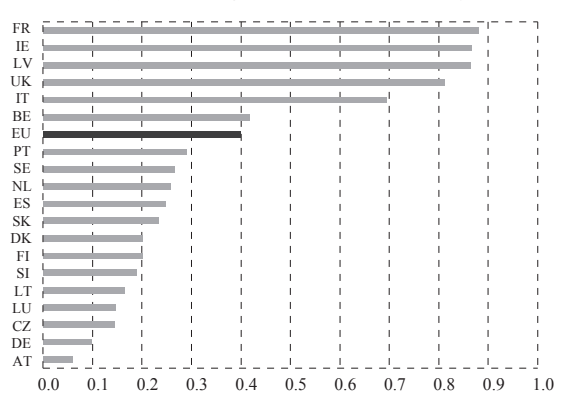

(b) Estimated efficiency vs. implicit rate

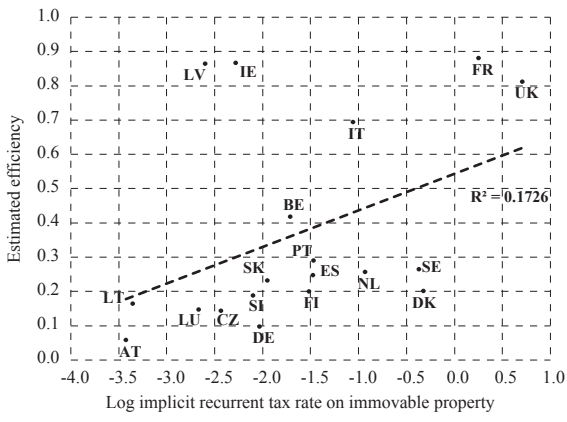

Source: Authors' construction based on Model 12.

According to figure 6, Austria, Germany, Czech Republic and Luxembourg are the least efficient countries, while France, the UK and Italy are among the most efficient. However, Ireland and Latvia deserve special attention, as they are the only two countries with a low implicit property tax rate, but high efficiency. There are two possible reasons for the results of these two countries. On the one hand, we know that both countries were among those with fewer observations. On the other hand, the estimated functions might be omitting specific characteristics, at a country level, that affect the capacity to increase the tax revenue. In some cases, such as Ireland, the expected revaluation of the local property tax would contribute to tax broadening and tax revenue. These findings support the idea of raising recurrent property tax rates or bases to increase government revenue.

\section{CONCLUSIONS}

Despite the rise in house prices since 2014, proceeds from property taxation are still somewhat limited in developed countries compared with other government revenue categories. There is a general trend of low collection of property tax. The explanation of this trend seems to be a combination of absence of taxes (e.g. capital gains, wealth), low tax rates (e.g. reduced VAT), and/or the widespread application of tax exemptions (e.g. heritage and gifts). This may lead to low effective tax rates, i.e. the difference between the tax rate and the degree of tax exemptions. Moreover, several countries seem to have outdated house valuation systems and thresholds, which undermines the taxing potential of property taxation. Hence, it is not possible to conclude whether a jurisdiction is over-taxing or under-taxing when compared with peers in advanced countries. Nevertheless, we have provided some rankings of efficiency based on the recurrent taxation and implicit tax rates.

Overall, property taxation can be a useful tool at the disposal of governments for raising revenue and managing public finances. Raising effective property tax rates and bases can help to finance reductions in other more distortionary taxes or for consolidating public finances. This particularly applies to recurrent property taxes 
according to economic growth considerations and to other property taxes based on inequality considerations.

This article does not include the consequences of the COVID-19 pandemic crisis, which may impact household income and the government needs for revenue-raising tools to finance the higher expenditure needed to mitigate the crisis. Potential areas of reform on property tax would also need to balance the adverse equity effects in the most vulnerable groups (e.g. social housing) and population trends (e.g. migration and ageing).

\section{Disclosure statement}

No potential conflict of interest was reported by the authors. 


\section{REFERENCES}

1. Acosta-Ormaechea, S. and Yoo, J., 2012. Tax Composition and Growth: A Broad Cross-Country Perspective. IMF Working Papers, 12(257). https://doi. org/10.5089/9781616355678.001

2. Arnold, J., 2008. Do Tax Structures Affect Aggregate Economic Growth? OECD Economics Department Working Papers, No. 643. https://doi.org/10. 1787/236001777843

3. Bahl, R. W. and Martínez-Vasquez, J., 2008. The Determinants of Revenue Performance. In: R. Bahl, J. Martinez-Vazquez and J. Youngman (eds.) Making the Property Tax Work: Experiences in Developing and Transitional Countries. Cambridge: Lincoln Institute of Land Policy, pp. 35-57.

4. Barrios, S. [et al.], 2019. Housing taxation: a new database for Europe. JRC Working Papers on Taxation and Structural Reforms, No. 08/2019.

5. Cavalleri, M. C., Cournède, B. and Ziemann, V., 2019. Housing markets and macroeconomic risks. OECD Economics Department Working Papers, No. 1555. https://doi.org/10.1787/737133d8-en

6. Cournède, B., Goujard, A. and Pina, Á., 2013. How to Achieve Growth- and Equity-friendly Fiscal Consolidation? A Proposed Methodology for Instrument Choice with an Illustrative Application to OECD Countries. OECD Economics Department Working Papers, No. 1088. https://doi.org/10.2139/ssrn.2650018

7. ECB, 2017. The composition of public finances in the euro area. Economic Bulletin, (5), pp. 44-62.

8. ECB, 2020. The Household Finance and Consumption Survey: Results from the 2017 wave. ECB Statistics Paper Series, (36).

9. Elinder, M. and Persson, L., 2017. House price responses to a national property tax reform. Journal of Economic Behaviour \& Organization, 144 (December), pp. 18-39. https://doi.org/10.1016/j.jebo.2017.09.017

10. ESRB, 2019. Methodologies for the assessment of real estate vulnerabilities and macroprudential policies: residential real estate. Frankfurt am Main: European Systemic Risk Board.

11. European Commission, 2012. Possible reforms of real estate taxation: Criteria for successful policies. Occasional Papers, No. 119.

12. European Commission, 2015. Housing taxation: from micro design to macro impact. Criteria for successful policies. Quarterly report on the euro area, 14 (1), pp. 27-33.

13. Fatica, S. and Prammer, D., 2018. Housing and the Tax System: How Large Are the Distortions in the Euro Area? Fiscal Studies, 39(2), pp. 299-342. https://doi.org/10.1111/1475-5890.12159

14. Fenochietto, R. and Pessino, C., 2013. Understanding Countries' Tax Effort. IMF Working Paper, No. 13(244). https://doi.org/10.5089/9781484301272.001

15. Förster, M., Llena-Nozal, A. and Nafilyan, V., 2014. Trends in Top Incomes and their Taxation in OECD Countries. OECD Social, Employment and Migration Working Papers, No. 159. https://doi.org/10.1787/5jz43jhlz87f-en 
16. Grdinić, M., Drezgić, S. and Blažić. H., 2017. An Empirical Analysis of the Relationship between Tax Structures and Economic Growth in CEE Countries. Ekonomicky časopis, 65(5), pp. 426-447.

17. IMF, 2018. Fiscal Monitor: Capitalizing on Good Times. Washington: IMF.

18. Kumbhakar, S. C. and Lovell, C. A. K., 2004. Stochastic frontier analysis. Cambridge: Cambridge University Press.

19. Lequiller, F. and Blades, D., 2014. Understanding National Accounts: Second Edition. Paris: OECD.

20. Norregaard, J., 2013. Taxing Immovable Property, Revenue Potential and Implementation Challenges. IMF Working Paper, 13(129). https://doi.org/10. 5089/9781484369050.001

21. OECD, 1972. Global Revenue Statistics Database. Paris: OECD.

22. OECD, 2013a. Choosing fiscal consolidation instruments compatible with growth and equity. Economic Policy Papers, (7). https://doi.org/10.1787/5k43 nxq6dzd4-en

23. OECD, 2013b. How's Life? Measuring Well-being. Paris: OECD.

24. OECD, 2018. Taxation of Households Savings. OECD Tax Policy Studies, (25). Paris: OECD.

25. OECD, 2019a. Affordable Housing Database. Paris: OECD.

26. OECD, 2019b. Tax Policy Reforms 2019: OECD and Selected Partner Economies. Paris: OECD. https://doi.org/10.1787/ea8c26cf-es

27. Piketty, T. and Saez, E., 2013. A theory of optimal inheritance taxation. Econometrica, 81(5), pp. 1851-1886. https://doi.org/10.3982/ecta10712

28. Rodríguez-Vives, M., 2019. The quality of public finance: where do we stand? Economics and Business Letters, 8(2), pp. 97-105. https://doi.org/10.17811/ ebl.8.2.2019.97-105

29. Roeger, W. and Veld, J., 2010. Fiscal stimulus and exit strategies in the EU: a model-based analysis. European Economy - Economic Papers, No. 426. 


\section{TABLE A1}

Taxing tools in the housing market

$\begin{array}{ll}\text { Policy tool } & \text { Definition }\end{array}$

Refers to the one-off transaction tax for the sale of real estate either for the first time or subsequent times. It typically takes the form of stamp duty, VAT (first transaction), transaction tax, or capital acquisition tax. Purchase costs usually are not deductible in the tax declaration. This tax is widely applied in advanced countries as it is

1. Buying property administratively appealing since transactions can often be reasonably easily observed. These taxes could also contribute to reducing asset price volatility. However, taxing real estate transactions may also lead to undesirable outcomes, such as adversely impacting labour mobility, reducing house affordability, and ownership ratios.

\begin{tabular}{|c|c|c|c|}
\hline $\begin{array}{l}\text { Value added tax } \\
\text { (VAT) }\end{array}$ & $\begin{array}{l}\text { VAT on the value of } \\
\text { the property, sold for } \\
\text { the first time }\end{array}$ & \multirow{2}{*}{$\begin{array}{l}\text { Generate government } \\
\text { revenue } \\
\text { Reduce housing } \\
\text { demand (especially } \\
\text { speculative house } \\
\text { purchases) }\end{array}$} & D.211 \\
\hline $\begin{array}{l}\text { Stamp taxes/transfer } \\
\text { tax }\end{array}$ & $\begin{array}{l}\text { One-off - Transaction } \\
\text { taxes } \\
\text { All investors } \\
\text { (domestic/foreign); } \\
\text { borrowers/equity }\end{array}$ & & $\begin{array}{l}\text { D. } 214 \text { B, C } \\
\text { Stamp taxes } \\
\text { Taxes on financial } \\
\text { and capital } \\
\text { transactions }\end{array}$ \\
\hline
\end{tabular}

This involves recurrent taxes on property, usually levied at subnational/local level. It is particularly appealing as a source of localgovernment finance since property values reflect the benefits of local public spending. This type of tax is somehow underutilised. It is attractive in the sense that the base is relatively immobile and hard to hide, the tax comes at the top of the hierarchy of long-run growth-

2. Holding property friendliness mentioned earlier, and it can be made progressive through a basic allowance or by varying the rate with the value of the property. However, it requires some intense administrative build-up and maintenance of infrastructure. Income from owner-occupied property, whether in the form of imputed rental income or capital gains, is typically untaxed or taxed at low rates. It also includes recurrent taxes on net wealth (assets less liabilities), but they have been declining and only four countries are currently using them. ${ }^{15}$ Taxes paid annually and linked to the value of the property. Households: Current

Recurrent taxes on immovable property taxes on capital, other (D.59)

Other: Taxes on land Generate government revenue Finance regional/ local level services
D.59 Current taxes on capital buildings or other structures (D.29)

\begin{tabular}{lll}
\hline $\begin{array}{l}\text { Recurrent taxes } \\
\text { on net wealth }\end{array}$ & $\begin{array}{l}\text { Assets minus } \\
\text { liabilities }\end{array}$ & $\begin{array}{l}\text { D.59 Current taxes } \\
\text { on capital }\end{array}$ \\
\cline { 2 - 2 } $\begin{array}{l}\text { Other recurrent taxes } \\
\text { on property }\end{array}$ & $\begin{array}{l}\text { Other recurrent } \\
\text { taxes on capital }\end{array}$ & $\begin{array}{l}\text { D.59 Current taxes } \\
\text { on capital }\end{array}$ \\
\hline
\end{tabular}

${ }^{15}$ Spain, Iceland, Norway, and Switzerland. 


\begin{tabular}{|c|c|c|c|}
\hline Policy tool & Definition & Primary objective & Regulation \\
\hline Taxation & & & ESA 2010 \\
\hline 3. Renting property & \multicolumn{3}{|c|}{$\begin{array}{l}\text { Residential rental property is typically taxed on a comprehensive } \\
\text { basis, in a similar way to interest income. No tax relief is provided } \\
\text { upfront, and returns are taxed as they are earned-marked. }\end{array}$} \\
\hline Rental income & $\begin{array}{l}\text { Property income and } \\
\text { personal income tax } \\
\text { (PIT) }\end{array}$ & $\begin{array}{l}\text { Generate government } \\
\text { revenue }\end{array}$ & D. 45 and D.5 \\
\hline 4. Selling property & \multicolumn{3}{|c|}{$\begin{array}{l}\text { When people sell residential property for more than the purchase } \\
\text { price, they generally realize a capital gain that is subject to taxation } \\
\text { as income. The capital gain is defined as the difference between } \\
\text { selling and purchase prices, also known as the basis. Capital gains } \\
\text { taxes on the sale of residential properties are treated differently } \\
\text { depending on the holding period. Long-term capital gains relate to } \\
\text { dwellings held for more than a year, and are usually taxed with lower } \\
\text { rates and have a tax-free threshold for owner-occupied housing to } \\
\text { protect household net wealth. Short-term capital gains are generated } \\
\text { when the sale of the dwelling is made within a year, and are usually } \\
\text { taxed with higher rates to avoid housing bubbles. }\end{array}$} \\
\hline $\begin{array}{l}\text { Other non-recurrent } \\
\text { taxes on property }\end{array}$ & $\begin{array}{l}\text { Capital gains taxes } \\
\text { (occasional or } \\
\text { exceptional levies } \\
\text { on capital or wealth) }\end{array}$ & $\begin{array}{l}\text { Inequality } \\
\text { Reduce housing } \\
\text { demand and supply }\end{array}$ & D.91 Capital levies \\
\hline 5. Bequest & \multicolumn{3}{|c|}{$\begin{array}{l}\text { This includes taxes on inheritances and gifts. The yield is usually } \\
\text { relatively limited: rates are low, and exemptions and special } \\
\text { arrangements create multiple avoidance opportunities. The yield in } \\
\text { the countries with the highest returns (about } 0.7 \% \text { of GDP in Belgium } \\
\text { and France) suggests its potential as a revenue raising tool. The } \\
\text { main policy objective of inheritance taxes is to limit the } \\
\text { intergenerational transmission of inequality, but they also produce } \\
\text { distortions, which are difficult to assess. Theoretical results on } \\
\text { optimal bequest taxation differ widely, but Piketty and Saez (2013) } \\
\text { find a positive and relatively high rate. }\end{array}$} \\
\hline $\begin{array}{l}\text { Inheritance and gift } \\
\text { taxes }\end{array}$ & $\begin{array}{l}\text { Death duties or taxes } \\
\text { on gifts inter-vivos, } \\
\text { to be levied on the } \\
\text { capital of the } \\
\text { beneficiaries }\end{array}$ & $\begin{array}{l}\text { Inequality } \\
\text { Generate government } \\
\text { revenue }\end{array}$ & $\begin{array}{l}\text { D. } 91 \text { Taxes on capital } \\
\text { transfers }\end{array}$ \\
\hline
\end{tabular}


TABLE A2

Summary of panel data variables (selected EU countries, 1995-2017)

Variable Mean Std. dev. Min Max

Observations

Log implicit recurrent tax rate on immovable property $\frac{\text { Mean }}{\text { overall }} \frac{-1.49}{\text { between }}$

$\frac{\overline{\text { between }}}{\text { within }}-\frac{1.21}{1.13} \frac{-3.42}{-3.77} \frac{0.71}{-0.11} \frac{\mathrm{n}=19}{\mathrm{~T}=19.2}$

Growth of stock dwellings

\begin{tabular}{|c|c|c|c|}
\hline overall & 1.96 & 0.99 & 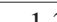 \\
\hline
\end{tabular}

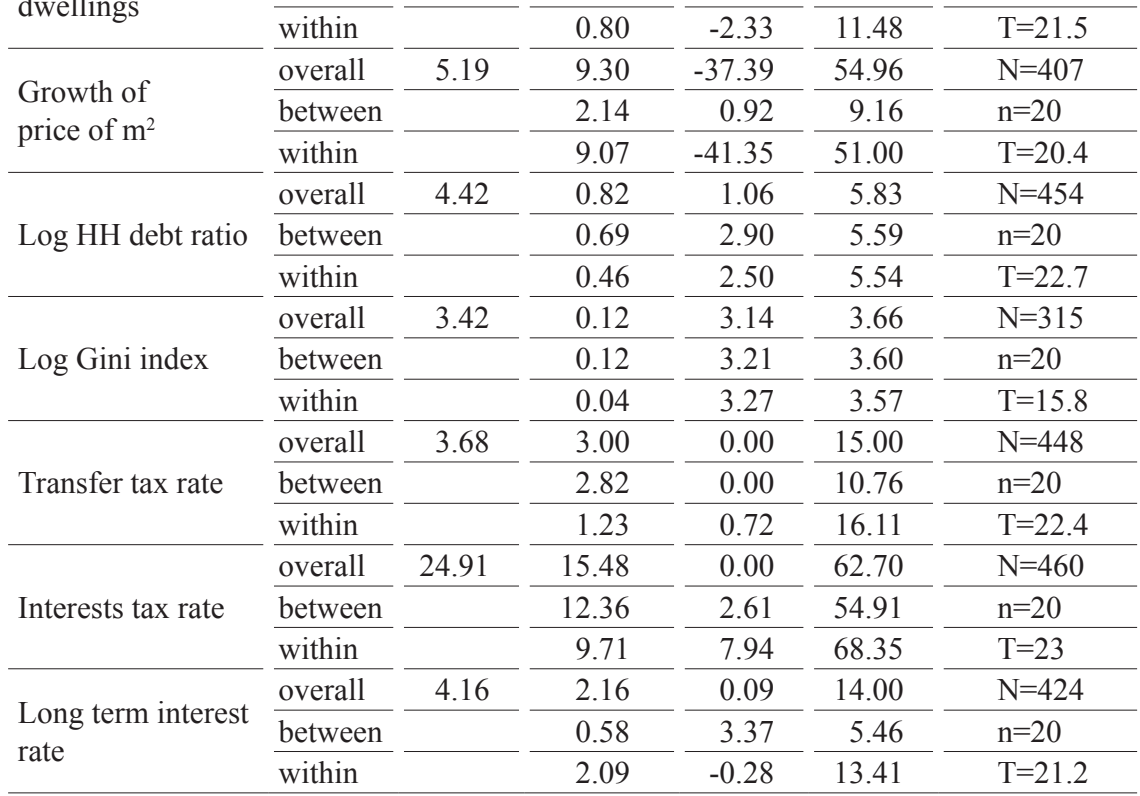

Note: " $N$ " denotes number of observations, " $n$ " number of countries and " $T$ " average period observed per country. 
Table A3

Estimated tax efficiency by country (selected EU countries, 1995-2017)

\begin{tabular}{|c|c|c|c|c|c|c|c|}
\hline Country & $\begin{array}{c}\text { Average } \\
\text { Log-IRTRIP }\end{array}$ & Model 7 & Model 8 & Model 9 & Model 10 & Model 11 & Model 12 \\
\hline Austria & -3.4233 & 0.0237 & 0.0301 & 0.0402 & 0.0550 & 0.0604 & 0.0592 \\
\hline elgium & -1.7104 & 0.0891 & 0.1144 & 0.1717 & 0.2349 & 0.4260 & 0.4188 \\
\hline zech R. & -2.4327 & 0.0856 & 0.1272 & 0.0826 & 0.1381 & 0.1579 & 0.1443 \\
\hline enmark & -0.3223 & 0.3748 & 2757 & 0.2940 & 2245 & 0.1795 & 0.2021 \\
\hline inland & -1.5155 & 0.1036 & 0.1254 & 0.1463 & 0.1820 & 0.2047 & 0.2007 \\
\hline rance & 2522 & 5455 & 0.6615 & 0.5756 & 0.7111 & 0.8747 & 0.8814 \\
\hline ermany & -2.0309 & & 0.0695 & 0.0699 & 0.0923 & 0.0972 & 0.0983 \\
\hline Ireland & -2.2790 & 0.7220 & 0.8587 & 0.7228 & 0.8625 & 0.8586 & 0.8674 \\
\hline Italy & & & & 0.44 & & & 0.6948 \\
\hline atvia & -2.5971 & 0.3355 & 0.3913 & 0.8366 & 0.8588 & 0.8642 & 0.8650 \\
\hline ithuania & -3.3523 & 0.1092 & 0.1470 & 0.1130 & 0.1722 & 1670 & 0.1651 \\
\hline uxembourg & -2.6653 & 0.0541 & 0.0557 & 0.1003 & 0.1074 & 0.1466 & 0.1479 \\
\hline Netherlands & -0.9303 & 0.1735 & 0.1319 & 0.2258 & 0.1857 & 0.2338 & 0.2576 \\
\hline ortugal & -1.4678 & & & 0.2491 & 0.2589 & 0.2514 & 0.2909 \\
\hline Slovakia & -1.9490 & 0.1375 & 0.2019 & 0.1566 & 0.2600 & 0.2405 & 0.2327 \\
\hline Slovenia & -2.0983 & 0.1254 & 0.1848 & 0.1183 & 0.1972 & 0.2022 & 0.1889 \\
\hline Spain & -1.4739 & 0.1103 & 0.1231 & 0.1700 & 0.1939 & 0.2460 & 0.2482 \\
\hline Sweden & -0.3691 & 0.2843 & 0.2787 & 0.2614 & 0.2663 & 0.2530 & 0.2655 \\
\hline UK & & & & & 0.8775 & & 0.8125 \\
\hline Average & -1.4934 & 0.2738 & 0.3013 & 0.3288 & 0.3689 & 0.3919 & 0.3989 \\
\hline
\end{tabular}

Note: The scores are scaled between 0 and 1. 